\title{
A Descriptive Analysis on the Factors of Alleviating Poverty among Women Entrepreneurs
}

\author{
Nik Syuhailah Nik Hussin, Nik Madeeha Nik Mohd Munir, Zuraimi Abdul Aziz, Siti Fariha Muhamad, \\ and Mohd Rafi Yaacob
}

\begin{abstract}
In the recent years, the influx of women in business continues to record poor performance in combating the poverty. Poverty is rampant and become main issue in developing countries, as it will improve the socioeconomic of the countries. The objective of this research is to find out the contributing factors in alleviating poverty for women entrepreneurship. A total of 196 samples were collected from women entrepreneurship in Terengganu and Kelantan. Data analysis was conducted using SPSS 20.0. The results indicate that the personality, cultural, environment, microfinance and entrepreneurial were the factors influenced in alleviating poverty among women entrepreneurs.
\end{abstract}

Index Terms-Contributing factors, poverty alleviation, women entrepreneurs, entrepreneurship, microfinance.

\section{INTRODUCTION}

Poverty improvement has become a key objective in Malaysian development plans subsequent to the development of New Economic Policy and National Development Policy. Encouraged by the microcredit programme in Bangladesh, as initiated by Muhammad Yunus, Malaysia introduced a microfinance programme as one of the poverty eradication programme in the country. Even though the elimination of poverty is essential, the microfinance programme also hoped to lessen the level of dependency among the poor people on the government by stimulating the concept of self-reliance.

In order to overcome poverty, accessibility towards financial services is essential. Thus, microfinance plays a vital role in fighting poverty. Microfinance program has become more substantial as the main benefactor in job creation and income generation in order to surge social wealth and economic status of the underprivileged people and eliminating poverty. Obviously, women unlike men are motivated enough to increase economic status of their families, they are working hard for their family and they have entrepreneurial inclination which yet explored and developed. On top of that women are good payers of loan that they committed. But nevertheless, women access to finance especially from conventional banks in developing countries is limited, hampering poverty alleviation. In this regard, if ones want address poverty it is paramount importance to equip women with entrepreneurial knowledge and skills together will microfinance assistance as a means for them to

Manuscript received November 11, 2015; revised December 30. This work was supported by the Universiti Malaysia Kelantan under the Short Grant Research Scheme.

The authors are with the Faculty of Entrepreneurship and Business, Universiti Malaysia Kelantan, 16100 Kota Bharu, Kelantan, Malaysia (e-mail: niksyuhailah@umk.edu.my, nmadeeha@umk.edu.my, zuraimi@umk.edu.my, fariha@umk.edu.my,rafi@umk.edu.my). embark on small-scale business [1].

Due to the above facts, various microfinance program throughout the world have been overwhelmingly dedicated to women. Grameen bank in particular caters for poor women throughout Bangladesh. As in October 2011, Grameen Bank had 8.349 million borrowers, $97 \%$ of whom are women, with 2,565 branches, provided services in 81,379 villages, covering more than 97 percent of totally villages in Bangladesh (www.grameen.info.org). Looking at the success stories of micro finance concept of Grameen Bank in Bangladesh, many countries have replicated the model.

Basically, various institutions including non-banking institutions as well as government agencies have administered microfinance program in Malaysia. The government was instrumental in establishing Amanah Ikhtiar Malaysia (AIM) on 17 September 1987 especially to cater the needs of microfinance for women to help them in entrepreneurship. As at February 2015, total members of AIM increased to 356,458 with 137 branches throughout the country. Total amount of money released during that period was about RM12 billion [2], [3]. A part from Amanah Ikhtiar the government through various agencies such as TEKUN, Majlis Amanah MARA (The Trust of Bumiputra), Bank Simpanan Nasional (BSN), Yayasan Basmi Kemiskinan (YBK), Yayasan Pembangunan Usahawan (YPU), Yayasan Usaha Maju Sabah (YUM) also provides small loans to women who involve in business.

As far as literature of micro finance and poverty alleviation is concerned many studies pertaining to micro finance assistance from various agencies and their impacts have been conducted [4]-[6], but none look in-depth on the roles of personality, cultural, environment, microfinance, entrepreneurial factors and its relationship with poverty alleviation for women entrepreneurship. The main objective of this study is to investigate the role played by these factors to alleviate the poverty.

\section{LITERATURE REVIEW}

\section{A. Personality Trait}

Personality traits can be labeled as originators of entrepreneurial attention to business prospects. The ownership of certain personal qualities allows entrepreneurs to perform their functions well. The dearth of certain traits may freeze the evolving process for an individual to become an entrepreneur. Distinctive personal traits of entrepreneurs have been studied in the prior research such as desire for independence, need for achievement, self-possession, locus of control, risk taking propensity, knowledge and information and detection of chance. 
Numerous studies approve that with entrepreneurs, the capability of internal grasp is more articulated than with others [7], [8]. People who are internally encouraged to create companies that survive [9] as well as companies that are rising faster than others [10]. A tendency for risk-taking is a massively significant dimension in the area of entrepreneurship and refers to the people who are prompted to accept risks when faced the uncertainty [11]. Taking risk, fiscal, social as well as mental is essential in entrepreneurial process. Entrepreneurs are opposing to risks that are unruly in nature only oftentimes, due to their excessive self-possession and persuasion about their own dignity, they get into risky situations [12]. The power to recognize good business prospects as per individual is also an advantageous, especially in transforming a successful entrepreneur [13]. Recognizing opportunity is also the most essential feat in the entrepreneurial process. In many cases, all of the entrepreneurial process starts from this action [14].

\section{B. Cultural Factor}

Several cultural traditions may boost, or discourage an access to entrepreneurship. Thus, it is implied that the culture and characteristics of certain group of people will induce or deter the degree of an entrepreneurship. The concept of cultural dissimilarity has been interpreted by some as a powerful element of regional or national variation in the supply of entrepreneurship [15]. Previous research on the matter is relatively scarce and inconclusive though there have been works to justify the extreme growth in the economy from a sociological perspective, with respect to local groups. Earlier research has discussed that people who are holding different cultural values experience different stages of entrepreneurial activities [16]-[19]. The connection is complicated. In fact, when applied to native groups, previous works on this subject is general and often shows protective to the indigenous researcher.

\section{Business Environment}

The business atmosphere seems to be more substantial in bringing the prosperity to women entrepreneurial activity. The indigenous surroundings for business, accessibility of market access, steady condition of the nation's workforce, availability of the raw materials, appropriate process of product development are all necessary ingredients in job environment. The significant indicators in promoting successful entrepreneurial is the efficiency in marketing and production. However, most of the women entrepreneurs had the poor technical skills and managerial, and led to marketing inefficiency and less productive [20].

Challenges in business are one of the uncontrolled variables by the job proprietor and it is more likely depends on the business environment. Most of the entrepreneurial activities were determined by business factors. The reason is, despite the possession of the essential personal entrepreneurial characteristics such as accurate attitude to risk, command, energy and working skills, inspiration; the environment may obstruct women entrepreneurs from exploring the entrepreneurial opportunities [20]-[22]. Therefore, business knowledge is also one of the key components of the business environment. This knowledge includes the product scope and market activities. Job skills include managerial and expert skills could be obtained through sufficient training [23]. In developing countries, gender-related prejudices, among other business, environmental factors, also pose limitation to women entrepreneurial activity [24].

\section{Microfinance}

Over the past thirty years, assessment studies and researches in the field of microfinance have observed a noticeably growth among academic schools. However, majority of the studies had focused on the measurements of microfinance outputs rather than inputs [25]. Recently, the recognition of the importance of assessing both input and output in microfinance studies, and it has improved the microfinance implementation. The output of microfinance is varies among the institutions referring to microfinance's model and the range of the product. For example, microfinance can be in a group scheme or individual scheme. As for a group scheme, the group members form a joint in a liability group and make loans under the social security and they are responsible to repay the loans. On the other hand, the individual scheme services an individual borrower.

Several kinds of microfinance institutions provide different types of financial services. Some of them provides savings, insurance, loan, while others provide financial and nonfinancial products such as enterprises development training, social capital services, skills acquirement trainings and others. Thus, the performance on output in microfinance is depending on several criteria, which may gives different outcomes [26].

\section{E. Entrepreneurial Factor}

There were evidences in past studies that entrepreneurial factors significantly contribute to the success of entrepreneurs. This includes an internal locus of control [27], self-confidence, independence [28] and innovativeness as well as decision-making skills and good communication skills [29]. An entrepreneur also must be well prepared mentally and physically in order to face any possibilities during the new venture setup. [29] justified this as a risk taker whereby; taking risk is one of the significant factors in developing resilient entrepreneurial personality, which is useful for business activities [30]. Besides risk taking, high self-efficacy, opportunity recognition, persistence and social skills also part of critical characteristics that can lead to a successful entrepreneurs [31].

Honesty, ethics and spirituality are three important elements that [32] have been highlighted, in order to create a healthy and strong organization. Furthermore, entrepreneurs who is being creative and having technical and mental skills as well as good interpersonal contribute to an entrepreneur's success. On the other hand, [33] highlighted that; entrepreneurs may gain the extra value if he/she being practical, goal-oriented, determined, self- confident and flexible, whilst, knowledge that is gathered from various directions through formal or informal education such as personal experience or grooming is another significant component leading to a successful entrepreneur [34].

Being educated can make an entrepreneur to be innovative and creative by generating new ideas, which in turn qualifies entrepreneurs to grab the upcoming opportunities. Besides the attributes mentioned above, leadership is also another important factor that positively contributes to success in 
business [35]. Entrepreneurs need two cases of leadership competencies in order to deliver good and quality services; running and self-competencies [36]. Functional capabilities consist of four performance subsystems (i.e., finance, operations, human resources and marketing), while self-competencies comprises; encouraging the company instead of individual leader, utilizing external advisors intellectual integrity and producing a sustainable organization.

Support from others (either formal or informal) is one of the elements that may influence the success of entrepreneurs. Financial support, strategic partnership or industrial contacts and engineering science, can be classified as formal support [37]. On the other hand, community based networks and personal were labeled as informal support [38]. Additionally, in Hong Kong, the Chinese entrepreneurs performed in their businesses due to the practices of 'familisme', which involves the territorial background and kinship ethnicity, which tighten up the bond among the entrepreneurs, and thus, it create restrictions for others who are not from the family to enter the business [39]. To add further, [29] mentioned that money support for entrepreneurs could also occur in the diversity of mentoring.

\section{METHODOLOGY}

This study adopted a purposive sampling method, where the samples were obtained from a specific group of people, who could provide the desired information, because they are the only ones who have it, or conform to some criteria set by the study [40]. In order to ensure the accuracy of the data collected, small businesses which have satisfied the following criteria; it must have been in operation for at least one year and above; the firm must have not more than 75 full-time employees; the respondent must be the owner or manager of the firm; the firm is a participant in one of a microfinance program regardless from which organization.

A total of 250 self-administered questionnaires were distributed to the identified respondents located in Terengganu and Kelantan. However, after about two months of the data collection exercise, 196 (78.4 per cent response rate) questionnaires were considered to be legitimate and met the required criteria for this research. The sample size of 196 was sufficient according to Roscoe's (1975) rule of thumb (30 to 500 samples).

The questionnaire was divided into 3 sections. Section A asking respondents on the factors to alleviate the poverty. Section B is the measurement for respondent's poverty alleviation. Each items in section A and B is then measured with interval scales on a 5-point Likert Scale which 1 represent strongly disagree and 5 refers to strongly agree. Finally, section $\mathrm{C}$ comprises of questions on demographic information, which respondents need to mark the choice given. The data then was analyzed using SPSS 20.0 to obtain the result. The survey questionnaires were adapted from previous literatures.

The reliability test of Cronbach Alpha was conducted to check the internal consistency of the scales. The reliability coefficients of the six dimensions exhibit consistency; personality traits as measured by 5 items produce 0.820 , cultural factors with 5 items yield a coefficient value of
0.728 , environment factors of 8 items exhibit coefficient value of 0.847 , microfinance factors with 8 items produce 0.874 , entrepreneurial factor of 11 items exhibit coefficient value of 0.909 , and poverty alleviation as measured by 8 items produce 0.887 as shown in Table I.

TABLE I: RELIABILITY TEST

\begin{tabular}{lcc}
\hline Dimension & Items & Cronbach's Alpha coefficient \\
\hline Personality traits & 5 & 0.820 \\
Cultural factor & 5 & 0.728 \\
Environment factor & 8 & 0.847 \\
Microfinance factor & 8 & 0.874 \\
Entrepreneurial factor & 11 & 0.909 \\
Poverty alleviation & 8 & 0.887 \\
\hline
\end{tabular}

\section{RESULTS AND DISCUSSIONS}

A summary of the 196 samples in this study is shown in Table II. The majority of the participants were aged above 40 years old (60.2 per cent). In terms of the educational level, half of the respondents had attended secondary school (53.1 per cent) and majority of respondents had experienced of between 16 to 20 years (26.1 per cent) in business. It shows that most of the respondents started the business from their initiative (62.2 per cent) while others inherited the business from the family members.

TABLE II: DEMOGRAPHIC PROFILES

\begin{tabular}{lcc}
\hline Variables & Frequency $(n=196)$ & Percent $=100.0$ \\
\hline Age & 37 & 18.9 \\
20-29 years old & 41 & 20.9 \\
30-39 years old & 59 & 30.1 \\
40-49 years old & 59 & 30.1 \\
Above 50 years old & & \\
Education & 38 & 19.4 \\
Primary school & 104 & 53.1 \\
Secondary school & 31 & 15.8 \\
Tertiary education & 23 & 11.7 \\
Others & & \\
Experience & 29 & 14.9 \\
Less than 5 years & 42 & 21.4 \\
5-10 years & 43 & 22.0 \\
11-15 years & 51 & 26.1 \\
16-20 years & 31 & 15.6 \\
More than 20 years & & \\
Business start-up & 74 & 37.8 \\
Family inherit & 122 & 62.2 \\
Own initiative & & \\
\hline Source: Based on the sample survey & & \\
\end{tabular}

Table III shows the factor of personality traits of women entrepreneurship in this study. Most respondent agreed that self-confidence is the important item in the personal traits factor. In contrast, risk taking propensity is least importance for the personality traits factor for women entrepreneurship. This shows that to be successful in the business, respondents are required to increase their capabilities to deliver performance.

TABLE III: PERSONALITY FACTOR

\begin{tabular}{lcc}
\hline Items & Mean & Std. Deviation \\
\hline Self-confidence & 3.98 & 0.87 \\
Locus of control & 3.84 & 0.85 \\
Better position in society & 3.80 & 1.04 \\
Desire for independence & 3.76 & 0.98 \\
Risk taking propensity & 3.75 & 0.90 \\
\hline
\end{tabular}

The result in Table IV shows that the highest mean for cultural factor was presence of role model (3.78). This 
followed by business establishment (3.61), level of uncertainty (3.58), choice of career (3.55) and family background (3.43). Based on result, respondents believe that entrepreneurs were easily recognizes in the community through their achievement.

TABLE IV: CULTURAL FACTOR

\begin{tabular}{lcc}
\hline Items & Mean & Std. Deviation \\
\hline Presence of role model & 3.78 & 0.85 \\
Business establishment & 3.61 & 0.81 \\
Level of uncertainty & 3.58 & 0.82 \\
Choice of career & 3.55 & 0.85 \\
Family background & 3.43 & 1.06 \\
\hline
\end{tabular}

Table $\mathrm{V}$ shows the environment factor as a contributing factor in alleviating poverty. Results indicated that main factor in the environment as perceived by respondents were marketing opportunity, microfinance, social capital to create opportunity, social capital in providing opportunity and lack of employment (their mean scores were over 3.60). Most respondents agreed the above factors influence respondents to improve their business in order to alleviate the poverty.

\begin{tabular}{lccc}
\multicolumn{3}{c}{ TABLE V: ENVIRONMENT FACTOR } \\
\hline Items & Mean & Std. Deviation \\
\hline Marketing opportunity & & 3.72 & 0.80 \\
Microfinance & 3.68 & 0.88 \\
Social capital to creates & 3.66 & 0.83 \\
$\begin{array}{l}\text { opportunity } \\
\text { Social capital provides }\end{array}$ & 3.65 & \\
opportunity & & 0.79 \\
Lack of employment & & 3.61 & 0.97 \\
Technology & 3.55 & 0.85 \\
Government and local authority & 3.50 & 0.81 \\
Competition & 3.45 & 0.91 \\
\hline
\end{tabular}

The highest mean score in the microfinance factor was saving method as shown in Table VI. It shows score of 3.67. Second highest mean score was loan financing (3.56) and third highest mean was business services and training (3.53). Meanwhile, respondents agreed that others factors such as reasonable interest, business establishment by social group, training, flexible repayment and social networking were mean scores under 3.50. Respondents believed that structured saving method and loan financing management were increased the capability of respondent to deliver good performance.

\begin{tabular}{lcc}
\multicolumn{3}{c}{ TABLE VI: MicROFINANCE FACTOR } \\
\hline Items & Mean & Std. Deviation \\
\hline Saving method & 3.67 & 0.81 \\
Loan financing & 3.56 & 0.92 \\
Business services and training & 3.53 & 0.80 \\
Reasonable interest & 3.47 & 0.86 \\
Business establishment $\quad$ by & 3.43 & 0.87 \\
social group & & \\
Training & 3.41 & 0.89 \\
Flexible repayment & 3.39 & 0.93 \\
Social networking & 3.38 & 0.92 \\
\hline
\end{tabular}

Table VII shows the descriptive analysis of the entrepreneurial factor in this study. Altogether there were eleven items under this variable such as good ethic, communication skill, knowledge, risk taker, motivation, leadership, entrepreneurship skill, teamwork, high achievement, innovative and creative. The result shows that the mean score above 3.80 were communication skill, good ethic, knowledge and entrepreneurship skill, which were $3.90,3.86,3.85$ and 3.83 respectively. This result shows that most respondents were capable in communication skill, implementing a good ethic in doing their business as well as knowledge with entrepreneurship skill in handling the business.

TABLE VII: ENTREPRENEURIAL FACTOR

\begin{tabular}{lcc}
\hline Items & Mean & Std. Deviation \\
\hline Communication skill & 3.90 & 0.87 \\
Good ethic & 3.86 & 0.80 \\
Knowledge & 3.85 & 0.84 \\
Entrepreneurship skill & 3.83 & 0.80 \\
High achievement & 3.78 & 0.90 \\
Leadership & 3.77 & 0.79 \\
Teamwork & 3.71 & 0.88 \\
Risk taker & 3.68 & 0.86 \\
Motivation & 3.66 & 0.84 \\
Creative & 3.50 & 0.81 \\
Innovative & 3.48 & 0.84 \\
\hline
\end{tabular}

Table VIII reports the mean scores of the poverty alleviation characteristics with 8 items. The highest mean score goes to increase of sales. The second highest score was recorded for item increase of social status and then closely followed by item of positive perception of personality. In contrast, sharing with community is least importance for the measurement of poverty alleviation. This shows that most respondents were looking into the acceptance of respondents within the community.

\begin{tabular}{|c|c|c|c|}
\hline Items & & Mean & Std. Deviation \\
\hline Increase of sales & & 3.59 & 0.81 \\
\hline Increase of social status & & 3.52 & 0.81 \\
\hline $\begin{array}{ll}\text { Positive } & \text { perception } \\
\text { personality } & \end{array}$ & of & 3.51 & 0.86 \\
\hline Business expansion & & 3.47 & 0.89 \\
\hline Increase of income & & 3.45 & 0.87 \\
\hline Diversity of products & & 3.43 & 0.93 \\
\hline $\begin{array}{l}\text { Positive perception } \\
\text { community }\end{array}$ & in & 3.40 & 0.86 \\
\hline Sharing with community & & 3.31 & 0.93 \\
\hline
\end{tabular}

\section{CONCLUSION}

This study evaluated the contributing factors including personality traits, cultural factor, environment factor, microfinance and entrepreneurial factor. Most respondents agreed the self-confidence is required for entrepreneurs in order for them to manage their business successfully. With regards to cultural factors, by proving their achievement in the community is encouraged respondents to be role model. In term of environment factor, respondents agreed that marketing opportunity is very importance for them to explore in depth so that they are able to sustain in the market. Moreover, respondents are agreed that saving method is the highest priority for them when they are manages their business. Respondents are also agreed communication skill in managing business will help them to deliver business performance. Increase of sales is the highest factor in measuring the poverty alleviation.

\section{ACKNOWLEDGEMENT}

Authors are very thankful to the University Malaysia Kelantan for the financial support through the Short Grant 
Research Scheme to carry out this study.

\section{REFERENCES}

[1] M. Yunus and A. Jolis, Banker to the Poor, Public Affairs, Philadelphia, 1999.

[2] Amanah Ikhtiar Malaysia. (2015). Total member of AIM as at February 2015. [Online] Available: http://www.aim.gov.my/2013-04-19-07-04-25/2013-04-19-07-04-26/j umlah-sahabat

[3] Amanah Ikhtiar Malaysia. (2015). Total funding as at February 2015. [Online] Available: http://www.aim.gov.my/2013-04-19-07-04-25/2013-04-19-07-04-26/ pengeluaran-pembiayaan

[4] M. Rosman and M. M. Rosli, "Microcredit position in micro and small enterprise performance: The Malaysian case," Management Research Review, vol. 36, no. 5, pp. 436-453, 2013

[5] C. Z. C. Din, "Creating a conducive environment for micro and rural finance - The Malaysian experience," in Proc. High-level Policy Marketing on Micro Finance and Rural Finance in Asia, Yogyakarta, Indonesia, 2004.

[6] M. Rozita, "Ikhtiar microcredit programme. The experience of Amanah Ikhtiar Malaysia (AIM)," in Proc. Pembentangan/Taklimat Kepada Delegasi United Nation Development Programme (UNDP) dan Jabatan Perdana Menteri, di Cawangan AIM Pulau Pinang, 2007.

[7] D. B. Greenberger and D. L. Sexton, "An interactive model for new venture creation," Journal of Small Business Management, vol. 26, no. 3, pp. 107-118, 1988 .

[8] S. Caird, "The enterprising tendency of occupational groups," International Small Business Journal, vol. 9, no.4, pp. 75-81, 1991.

[9] J. Gimeno, T. B. Folta, A. C. Cooper, and C. Y. Woo, "Survival of the fittest? Entrepreneurial human capital and the persistence of underperforming firms," Administrative Science Quarterly, vol. 42, no. 4, pp. 750-783, 1997

[10] D. Lee and E. Tsang, "The effects of entrepreneurial personality background and network activities on venture growth," Journal of Management Studies, vol. 38, no. 4, pp. 583-602, 2001.

[11] Y. Gurol, and N. Atsan, "Entrepreneurial characteristics amongst university students: Some insights for entrepreneurship education and training in Turkey," Education \& Training, vol. 48, no. 1, pp. 25-38, 2006.

[12] B. Wu and A. M. Knott, "Entrepreneurial risk and market entry," Management Science, vol. 52, no. 9, pp. 1315-1330, 2006

[13] S. Shane and S. Venkataraman, "The promise of entrepreneurship as a field of research," Academy of Management Review, vol. 25, no. 1, pp. 217-226, 2000

[14] R. A. Baron, "Opportunity recognition as pattern recognition: How entrepreneurs 'connect the dots' to identify new opportunities," Academy of Management Perspectives, vol. 20, no. 1, pp. 104-119, 2007.

[15] P. Davidsson and J. Wiklund, "Values, beliefs and regional variations in new firm formation rates," Journal of Economic psychology, vol. 18, no. 2, pp. 179-199, 1997

[16] T. M. Begley and W. L. Tan, "The socio-cultural environment for entrepreneurship: A comparison between East Asian and Anglo-Saxon countries," Journal of International Business Studies, vol. 32, no. 3, pp. 537-555, 2001.

[17] S. Lee and S. Peterson, "Culture, entrepreneurial orientation, and global competitiveness," Journal of World Business, vol. 35, no. 4, pp. 401-416, 2000

[18] A. Morrison, "Entrepreneurship: What triggers it?" International Journal of Entrepreneurial Behaviour \& Research, vol. 6, no. 2, pp. 59-72, 2000

[19] S. L. Mueller and A. S. Thomas, "Culture and entrepreneurial potential: a nine country study of locus of control and innovativeness,' Journal of Business Venturing, vol. 16, no. 1, pp. 51-75, 2001.

[20] R. K. Shastri and A. Sinha, "The socio-cultural and economic effect on the development of women entrepreneurs (with special reference to India)," Asian Journal of Business Management, vol. 2, no. 2, pp. 30-34, 2010

[21] J. Kuzilwa, "The role of credit for small business success: A study of the National Entrepreneurship Development Fund in Tanzania," The Journal of Entrepreneurship, vol. 14, no. 2, pp. 131-161, 2005.

[22] R. Vob and C. Muller, "How are the conditions for high-tech start-ups in Germany," International Journal of Entrepreneurship and Small Business, vol. 7, no. 3, pp. 285-311, 2009.

[23] A. Salman, How to Start a Business: A Guide for Women, Pakistan Center for International Private Enterprise, Institute of National Endowment for Democracy, affiliate of the USA Chamber of Commerce, 2009.
[24] M. Otero, Bringing development back into microfinance, Kemiskinan di Malaysia (Poverty in Malaysia), Universiti Putra Malaysia Publication, 2010

[25] D. Hulme, "Impact assessment methodologies for microfinance: theory, experience and better practice," World Development, vol. 28 , no. 1, pp. 79-98, 2000.

[26] M. S. Robinson, The Microfinance Revolution, Sustainable Finance for the Poor, Washington, D.C.: World Bank, 2001.

[27] J. B. Rotter, "Generalized expectations for internal versus external control of reinforcement," Psychological Monographs: General and Applied, vol. 80, no. 1, pp. 1-27, 1996.

[28] R. D. Hisrich and M. V. Gracher, "The Russian entrepreneur: characteristics and prescription for success," Journal of Managerial Psychology, vol. 10, no. 2, pp. 3-9, 1995.

[29] C. Cox and R. Jennings, "The foundation of success: The development and characteristics of British entrepreneurs and intrapreneurs," Leadership and Organizational Development Journal, vol. 16, no. 7, pp. 4-9, 1995.

[30] R. K. Wadhaw, J. Davar, and B. P. Rao, Entrepreneur and Enterprise Management, India: Kanishka Publisher, 1998.

[31] G. Markman and R. Baron, "Person-entrepreneurship fit: Why some people are more successful as entrepreneurs than others," Human Resource Management Review, vol. 13, no. 2, pp. 281-301, 2003

[32] M. P. Kriger and B. J. Hanson, "A value-based paradigm for creating truly healthy organizations," Journal of Organizational Change Management, vol. 12, no. 4, pp. 302-317, 1999.

[33] S. S. Nandram and K. J. Samsom, "Attributes of Entrepreneurial Success and failures. New Perspectives gained from the Critical Incident Technique," in Proc. The small Business and Entrepreneurship Development Conference, 2002.

[34] H. E. Aldrich and M. A. Martinez, "Many are called but few are chosen: an evolutionary perspective for the study of entrepreneurship," Entrepreneurship Theory \& Practice, vol. 25, no. 4, pp. 41-56, 2001.

[35] J. P. J. Jong and D. N. D. Hartog, "How leaders influence employees' innovative behavior," European Journal of Innovation Management, vol. 10, no. 1, pp. 41-64, 2007.

[36] P. M. Swiercz and S. R. Lydon, "Entrepreneurial leadership in high-tech firms: a field study," Leadership and Organization Development Journal, vol. 23, no. 7, pp. 380-389, 2002

[37] C. Carrier, L. Raymond, and A. Eltaief, "Cyberentrepreneurship: A multiple case study," International Journal of Entrepreneurial Behavior \& Research, vol. 10, no. 5, pp. 349-363, 2004.

[38] T. Baycan-Levent, E. Masurel, and P. Nijkamp "Diversity in Entrepreneurship: Ethnic and female roles in urban economic life," International Journal of Social Economics, vol. 30, no. 11, pp 1131-1161, 2003.

[39] S. L. Wong, Emigrant Entrepreneurs: Shanghai Industrialists in Hong Kong, Oxford University Press, Hong Kong, 1998.

[40] U. Sekaran, Research Method for Business: A Skill Building Approach, United States: John Wiley \& Sons, 2003.

Nik Syuhailah Nik Hussin is a lecturer in Faculty of Entrepreneurship and Business, Universiti Malaysia Kelantan. She has a master in business administration and a bachelor degree in business administration (Hons). She is also a member of Institute Marketing Malaysia (MIMM). Her main areas of research interest are service marketing, management and microfinance. She has a total of almost 14 years of working experiences and she spent almost 12 years in banking industry before moved to a marketing line in Telecommunication industry. She was the account manager in Enterprise Sales and working directly with the management to develop and implement the marketing strategies for sales generation plan and maximize the potential prospective accounts. Prior to that, she gained valuable experiences in managing banking operations, which include service operations, wholesale banking and administration. She was the senior executive in the banking sector.

Zuraimi Abdul Aziz is a senior lecturer in Faculty of Entrepreneurship and Business, Universiti Malaysia Kelantan. He has a master in management and a bachelor degree in business administration (Hons). He is also a chartered member of The Chartered Institute of Logistics and Transport (CMILT) and a member of Institute Marketing Malaysia (MIMM). His main areas of research interest are logistics management, supply chain management, strategic management, operations management and port, shipping \& maritime transportation management. He has a total of almost 15 years of working experience in industry before joining the academic field. He spent almost 10 years in oil \& gas and petrochemicals companies, managing strategic planning, business development and trading, export and import management, commercial shipping and maritime transportation, supply 
chain management and logistics activities which consist of planning, sales \& procurement, operations, chartering and commercial. He was the head in strategic planning, commercial shipping and logistics department with Oil \& Gas and Petrochemicals companies and he focused on clean product petroleum, petrochemicals product including aromatics and olefin and gas. prior to that, he gained valuable experiences in port and customs procedures when he was attached with Malaysian ports and Malaysian customs.

Mohd Rafi Yaacob is an associate professor at the Faculty of Entrepreneurship and Business, Universiti Malaysia Kelantan. Currently, he is the deputy dean (Research and Innovation) at the faculty. He graduated from the Geography Department, University of Malaya in 1991 and worked as a tutor at the department from 1991 to 1994 . He pursued an MBA at the Middlesex University Business School (MUBS), United Kingdom in 1995 to
1996. He pursued a PhD at the Central Coast School of Business and Law, University of Newcastle, New South Wales, Australia in 2004 to 2007 under the International Postgraduate Research Student (IPRS) of the university. He earned a post graduate diploma in Entrepreneurship (PGDE) from the University of Cambridge, United Kingdom in early 2013. His cores academic teachings include entrepreneurship, research methodology and strategic environmental management. He is actively engaged in research projects on small medium enterprises (SMEs), strategic management, green business as well as corporate environmentalism. He has presented papers in national and international seminars, published articles in refereed journals, authored and co-authored of academic and motivational books. He is also a member of editorial advisory boards and reviewer of several national and international academic journals. 